\title{
Dieulafoy's lesion: an unexpected and rare cause of upper gastrointestinal bleeding
}

\author{
Saravana Kumar Rajanthran, ${ }^{1}$ Harjit Chaal Singh, ${ }^{1}$ Da Jun Than, ${ }^{1}$ Firdaus Hayati (i) 1,2
}

'Department of Surgery, Queen Elizabeth Hospital, Kota Kinabalu, Sabah, Malaysia ${ }^{2}$ Department of Surgery, Faculty of Medicine and Health Sciences, Universiti Malaysia Sabah, Kota Kinabalu, Sabah, Malaysia

\section{Correspondence to}

Dr Firdaus Hayati;

firdaushayati@gmail.com; m_ firdaus@ums.edu.my

Accepted 5 December 2020

Check for updates

(c) BMJ Publishing Group Limited 2020. No commercial re-use. See rights and permissions. Published by BMJ.

To cite: Rajanthran SK Singh HC, Than DJ, et al. BMJ Case Rep 2020;13:e240905. doi:10.1136/bcr-2020-

240905

\section{DESCRIPTION}

A 51-year-old man with multiple comorbidities of hypertension, chronic kidney disease, dyslipidaemia and a history of stroke was presented to the emergency department with a 1 day epigastric pain. He was subsequently diagnosed with hypertensive emergency and inferior myocardial infarction. Despite being administered an intravenous infusion of glyceryl trinitrate (GTN), his condition deteriorated and he developed cardiac arrest with ventricular fibrillation, which required cardiopulmonary resuscitation and defibrillation. The patient had stormy recoveries with multiple episodes of hospital-acquired pneumonia and prolonged intubation due to failed extubation. He was put on double antiplatelet medication and subcutaneous low-molecular weight heparins injection.

After 35 days in the coronary care unit (CCU), a coffee-ground fluid in the nasogastric tube was observed in the patient who also experienced several episodes of maelenic stools. Although his haemodynamic status was stable, his haemoglobin $(\mathrm{Hb})$ level however had dropped by $2 \mathrm{~g} / \mathrm{dL}$. This necessitated urgent bedside oesophagogastroduodenoscopy, which subsequently revealed a bleeding Dieulafoy's lesion (figure 1) at the lesser curvature of the stomach, about $5 \mathrm{~cm}$ from the cardio-oesophageal junction. Two endoscopic haemoclips were fixed at the base of the Dieulafoy's lesion (figure 2) and epinephrine injection was then administered. The commencement of these dual therapies consequently halted the bleeding. The endoscopy was completed up to the second part of the duodenum with no other abnormality found. Following a transfusion of two pints of packed cells, the patient's $\mathrm{Hb}$ level increased and remained static with no further evidence of recurrent bleeding. Two days later, he was started on nasogastric tube feeding. As for his

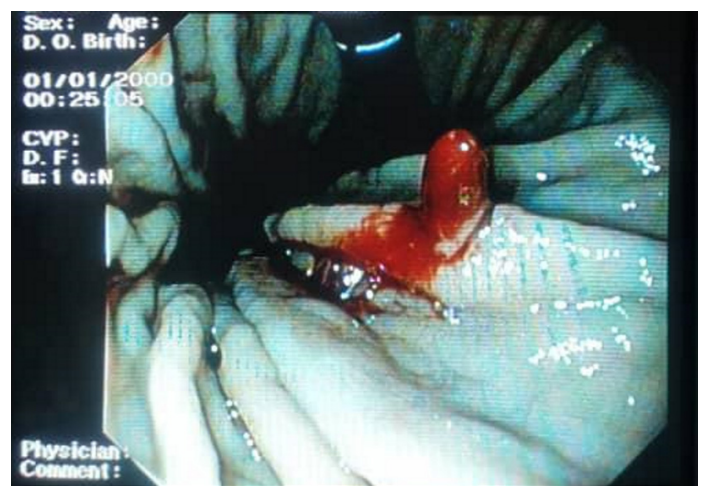

Figure 1 An endoscopy at retroflexed view showing a bleeding Dieulafoy's lesion.

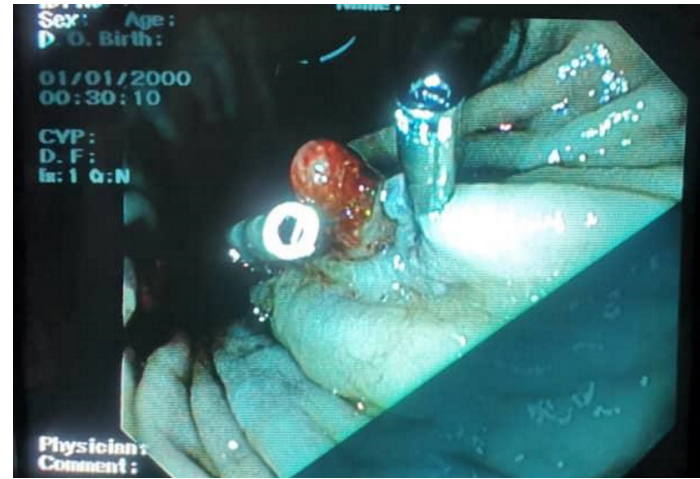

Figure 2 Two haemoclips were applied at the base of the Dieulafoy's lesion.

myocardial infarction, cardiology team decided not to put him on anticoagulant and double antiplatelet in view of the bleeding episode previously, a single antiplatelet was restarted back instead. $\mathrm{He}$ improved markedly and extubated, subsequently was warded for another 20 days and discharged well after being in CCU for a total of 55 days. Throughout the remaining days of his stay, there was no more gastrointestinal bleeding episode. On a follow-up visit in surgical clinic 1 month later, he is well, with no signs of gastrointestinal bleed.

Dieulafoy's lesion accounts for fewer than $2 \%$ of all gastrointestinal bleeding cases making it one of the most under-recognised conditions. ${ }^{1}$ The pathophysiology is undetermined although it is hypothetically postulated to be due to bleeding after erosion of the abnormally protruded dilated vessel, measuring up to $1-3 \mathrm{~mm}$ in diameter, which runs under the mucosa of the gastrointestinal tract. ${ }^{2}$ Preendoscopic therapy for bleeding Dieulafoy's lesion is identical to other management for gastrointestinal bleeding focusing on volume resuscitation, intragastric acid control and avoidance of consequent end-organ failure. Volume resuscitation via large-bore branula is initially performed with crystalline solution; this is, however, later substituted with transfusion of packed cells in any evidence of anaemia. Endoscopy remains the first diagnostic test and also functions as a therapeutic measure. Certain diagnostic criteria may be employed to establish Dieulafoy's lesion: (1) active arterial spurting or micropulsatile bleeding from small $(<3 \mathrm{~mm})$ mucosal defects surrounded by normal mucosa, (2) the presence of protruding vessels and (3) fresh adherent clots with a small point of attachment to the mucosal defect or normal mucosa. ${ }^{3}$ Angiography may be used to embolise obscure bleeding including Dieulafoy's lesions. When 
control efforts fail, surgery is warranted, as in about 3\%-16\% of cases comprising mostly patients with rebleeding after endoscopic therapies. ${ }^{4}$ Surgical interventions that could be employed include under-running of the lesion or wedge resection of the affected section of the gut. ${ }^{45}$ Advances in endoscopic techniques have however improved the detection rate of Dieulafoy's lesions, hence significantly decreasing its mortality incidences. ${ }^{4}$

\section{Patient's perspective}

I thank the managing doctors who had helped me to stop bleeding inside my stomach.

\section{Learning points}

- Acute upper gastrointestinal bleeding is a life-threatening condition, which impairs haemodynamic stability and warrants urgent life-saving endoscopic therapy.

- Dieulafoy's lesion must be considered in any case of obscure upper gastrointestinal bleeding.

- The pre-endoscopic approach is similar to other treatment for upper gastrointestinal bleeding, which focuses on volume resuscitation, intragastric acid control and avoidance of endorgan damage.
Acknowledgements We would like to thank the Director-General of Health Malaysia for his permission to publish this article as an interesting Clinical Image. In addition, we value the contributions to those who had involved directly or indirectly in publishing this case as a form of Clinical Image.

Contributors SKR wrote the manuscript. HCS provided the endoscopic figures. DJT did the literature searches. FH involved in managing the patient and provided the final review.

Funding The authors have not declared a specific grant for this research from any funding agency in the public, commercial or not-for-profit sectors.

Competing interests None declared.

Patient consent for publication Obtained.

Provenance and peer review Not commissioned; externally peer reviewed.

\section{ORCID iD}

Firdaus Hayati http://orcid.org/0000-0002-3757-9744

\section{REFERENCES}

1 Inayat F, Ullah W, Hussain Q, et al. Dieulafoy's lesion of the colon and rectum: a case series and literature review. BMJ Case Rep 2017;2017

2 Nojkov B, Cappell MS. Gastrointestinal bleeding from Dieulafoy's lesion: clinical presentation, endoscopic findings, and endoscopic therapy. World I Gastrointest Endosc 2015;7:295-307.

3 Jeon HK, Kim GH. Endoscopic management of Dieulafoy's lesion. Clin Endosc 2015;48:112-20.

4 Baxter M, Aly EH. Dieulafoy's lesion: current trends in diagnosis and management. Ann $R$ Coll Surg Engl 2010;92:548-54

5 Beatrice $\mathrm{P}$, Lucia R, Antonio G, et al. Rare case of upper gastrointestinal bleeding: Dieulafoy' S lesion of duodenum. A case report. Ann Med Surg 2019;45:19-21.

Copyright 2020 BMJ Publishing Group. All rights reserved. For permission to reuse any of this content visit

https://www.bmj.com/company/products-services/rights-and-licensing/permissions/

BMJ Case Report Fellows may re-use this article for personal use and teaching without any further permission.

Become a Fellow of BMJ Case Reports today and you can:

- Submit as many cases as you like

- Enjoy fast sympathetic peer review and rapid publication of accepted articles

- Access all the published articles

- Re-use any of the published material for personal use and teaching without further permission

\section{Customer Service}

If you have any further queries about your subscription, please contact our customer services team on +44 (0) 2071111105 or via email at support@bmj.com.

Visit casereports.bmj.com for more articles like this and to become a Fellow 